\title{
Globalization Of Entrepreneurship: Overwhelming Institutional Response In Favor Of SMEs In India
}

Sivakumar Venkataramany, Ashland University, USA

Daniel Fox, Ashland University, USA

\begin{abstract}
India's approach to the promotion of entrepreneurial firms is unique, and to some extent, overwhelming. The country has a dedicated ministry for small scale industries at the federal level supported by several agencies at federal and state levels. Besides, numerous commercial banks, regional rural banks, urban and cooperative credit lending institutions participate in funding the micro, small, and medium enterprises. Such an effort, though seemingly superfluous, is the dire need for a country to enhance the competitiveness of entrepreneurial firms in order to unite them under an organized structure and integrate their operations into that of major global firms. Three national-level Entrepreneurship Development Institutes are engaged in skill development. This paper offers a critique of the present policy with regards to the SMEs with a prospective outlook into their future.
\end{abstract}

\section{INTRODUCTION}

e ndia's approach to the promotion of entrepreneurial firms is unique, superfluous, and to some extent, overwhelming. The country has a dedicated ministry for small scale industries at the federal level supported by two agencies; namely, the Small Industry Development Organization (SIDO) and the National Small Industries Corporation Ltd (NSIC). The government has also set up a policy-making body known as the National Commission on Enterprises in the Unorganized Sector (NCEUS). Its role is to suggest policies and programs to address the wide range of issues affecting the productive potential of the large segment of the unorganized micro and small productive units. The role of the Ministry of Small Scale Industries is thus to mainly assist the states in their efforts to promote growth and development of the small scale sector, enhance its competitiveness in an increasingly market-led economy and generating additional employment opportunities. In addition, the ministry attempts to address issues of country-wide common problems of this segment and also undertake a role of advocacy on behalf of this sector. Small and medium enterprises (SMEs) contribute 7 percent to gross domestic product (GDP), constitute 34 percent of national exports, and account for 40 percent in the manufacturing sector. These units play an important role in their direct employment of more than 30 million people. These units in India are usually referred to as small-scale industries (SSI) and are always considered a major segment in the nation's priority sector together with agriculture for financial credit from all banking institutions.

Presently, the dynamics of business is undergoing a major transformation in the wake of globalization. The liberalization efforts pursued by India have opened new doors of opportunity and, at the same time, have also posed a new set of challenges in a knowledge-based economy. Therefore, a knowledge assessment must include not only economic parameters, but also other important aspects, such as education, health, emancipation of women, and an improvement in overall standard of living. This, if achieved, will ensure sustainable entrepreneurship [Jauhari 2007]. OECD countries have been able to address the funding gap through a resourceful venture capital market whereas developing economies, such as India and China, rely upon governmental support in the absence of fully developed private equity markets. Entrepreneurship in China and India has woken up and "the results could reshape business, politics, and society worldwide" [Khanna 2008]. The pace of entrepreneurs in both societies is so fast that their rules and laws can hardly keep up. This befits the spirit of entrepreneurship as "doing things in new ways, ahead of social 
norms and customs, and establishing the rules and laws' [Khanna 2008]. Emerging markets and emerging technologies present both challenges and opportunities for businesses and individual entrepreneurs in focusing on competitive advantages for their firms [Thukral et al 2008].

\section{RECENT LITERATURE REVIEW}

Factors such as firm-building capabilities, managerial skills, substantial supply of skilled labor and connection to markets are crucial for the initial development of the new economy clusters in technology and innovation driven entrepreneurship activities. Subsequently, increasing social returns and external effects arise after the clusters have been completely formed. The success of the Silicon Valley is direct evidence of these conditions. [Bresnahan et al 2001]. Selection of distribution channels to reach the end customer is as important as the production itself for the SMEs, particularly in a developing economy where the largest contribution is in the hands of these units [Singh et al 2007]. Development of additional industries in the vicinity alone will lead to economies of scale and technical advantage to foster rapid progress to the regional economy and to that of a nation [Sivastav et al 2007]. SMEs have an important role to play in integrating their operations with other small businesses and ultimately with global firms to justify their own existence and realize fruits of their complementary status. A dual strategy of vertical integration and horizontal cooperation is recommended for the local SMEs to work with global transnational corporations for the production of intermediate goods, and also for networking among local SMEs to link up with global firms for the production and marketing of consumer goods [Bala Subrahmanya 2007]. Economic size of an entrepreneurial unit may be measured by employment, output, fixed capital investment, and export variables and its economic performance may be indicated by output to capital ratio, output to labor ratio, and labor to capital ratio. Policy formulation may find empirical results to support a cluster approach rather than a dispersed approach for promotion and development of SSEs in India. The cluster approach has implications for establishing linkages between formal and informal SSEs and for elimination of smallness of dispersed SSEs [Narayana 2007].

In analyzing the proliferation of small scale family farms in India, Das contends that widespread involuntary unemployment in the rural economy may be considered a problem of failure to coordinate and such a problem can be overcome through planned, investment promotion by the state or regional administrations through reducing unemployment and inducing the entry of capitalist farmers [Das 2007]. The US has often served as a model for other countries to emulate in applying technology in the economy and of directing finance to smaller but innovative companies. As many technology companies are becoming rapidly globalised at early stages of their development by transferring or outsourcing part of their activities to emerging markets, Israel, China and India are experiencing rapid growth in risk-capital investments [OECD 2006]. SMEs have improved their performance and presence through industrial cluster approaches. Suitable cluster interventions are necessary for enhancing competitiveness and sustainability of the SME sector [Venkataramanaiah 2007].

Despite a characteristic and traditional entrepreneurial energy, both India and China lack an efficiently structured, professionally run, and inspirational corporate leadership. The three routes through which individuals in China and India become business leaders, namely, through pioneering, inheritance and the professional pathways, will help resolve this disconnect [Hedrick-Wong 2006]. An examination of the rapid growth of emerging markets such as China, India, and Vietnam, identifies two driving forces for their growth. First, economic reforms have changed prevailing laws, regulations, and implicit rules that dominate economic activity. Secondly, all three countries have experienced the emergence of new companies in which entrepreneurship plays a critical role [Daokui Li 2006]. Institutional entrepreneurs are those who help establish market institutions while conducting their traditional business activities.

\section{ENTRPRENEURSHIP IN A GLOBAL ECONOMY}

While most countries place most entrepreneurial firms in the category of small and medium-sized enterprises (SMEs), India refers to such firms as 'Micro, Small and Medium Enterprises' (MSME). After a longstanding demand from various entrepreneurs, small industry associations and related stakeholders for a single comprehensive legislation, the "Micro, Small and Medium Enterprises Development (MSMED) Act, 2006" was enacted. This is the first Act that provides for a precise definition of these enterprises besides paving way for a statutory National Board exclusively for them. This act also helps implement promotion schemes and addresses the 
development and enhancement of the firms' competitiveness. Table 1 offers a precise definition of the status of the entrepreneurial firms from the perspective of the original investment in productive assets excluding land and building.

\begin{tabular}{|c|c|c|}
\hline & \multicolumn{2}{|c|}{$\begin{array}{l}\text { Investment in plant and machinery/equipment (excluding } \\
\text { land and building) }\end{array}$} \\
\hline & Manufacturing Enterprises & Service Enterprises \\
\hline Micro & Up to $\$ 62,500$ & Up to $\$ 25,000$ \\
\hline Small & $\begin{array}{c}\text { Between } \$ 62,500 \text { and } \$ 1.25 \\
\text { million }\end{array}$ & $\begin{array}{c}\text { Between } \$ 25,000 \text { and } \$ 0.5 \\
\text { million }\end{array}$ \\
\hline Medium & $\begin{array}{l}\text { Between } \$ 1.25 \text { million and } \\
\qquad 2.5 \text { million }\end{array}$ & $\begin{array}{l}\text { Between } \$ 0.5 \text { million and } \\
\text { \$1.25 million }\end{array}$ \\
\hline
\end{tabular}

Source: SSI Annual Report 2006-07,

Ministry of Small Scale Industries, Government of India

These units are engaged in numerous productive activities in a society that is overall submerged in poverty related problems as shown in Table 2. Under such difficult circumstances, small businesses need support systems for sustenance, security, and success.

Table 2 Problems of Poverty

\begin{tabular}{|l|l|}
\hline Population in Poverty & $27.50 \%$ \\
\hline Urban & $25.70 \%$ \\
\hline Rural & $28.30 \%$ \\
\hline $\begin{array}{l}\text { Proportion of } \\
\text { Population below } \$ 1\end{array}$ \\
\begin{tabular}{l} 
(PPP) a day \\
\hline
\end{tabular}
\end{tabular}

Source: Asian Development Bank, “Key Indicators 2007”, Volume 38, 2007

With systematic economic liberalization being implemented, India is a potential candidate to reap the benefits of globalization. The programs and schemes undertaken by the federal ministry promote small scale industries by ensuring the following steps:

- $\quad$ adequate credit from financial institutions/banks

- funds for technology upgrading and modernization

- $\quad$ integrated infrastructural facilities

- $\quad$ modern testing facilities and quality certification laboratories

- $\quad$ access to modern management practices, entrepreneurship development and skill upgrading through appropriate training facilities

- $\quad$ assistance for better access to domestic and export markets

- $\quad$ cluster-wide measures to promote capacity-building and empowerment of the units

Table 3 offers a glimpse into the level of economic activity of the country as a whole for 2006. 
Table 3 Indicators of Productivity

\begin{tabular}{|l|c|c|c|}
\hline \multicolumn{2}{|c|}{ GDP (billions) } & \multicolumn{2}{c|}{$\$ 982.31$} \\
\hline \multicolumn{2}{|c|}{ Structure of Output } & \multicolumn{2}{c|}{ Growth of Output } \\
\hline Agriculture & $17.5 \%$ & GDP & $9.4 \%$ \\
\hline Industry & $27.9 \%$ & Agriculture & $2.7 \%$ \\
\hline Services & $54.6 \%$ & Industry & $10.9 \%$ \\
\hline & & Services & $11.0 \%$ \\
\hline
\end{tabular}

\section{INTERNATIONAL TRADE}

For an emerging market like India, it is important to keep its industrial output marked by a distinct degree of competitiveness. The result of such competitiveness will be evidenced by a marked increase in exports of output and an increase in imports for infrastructure and consumption. Table 4 offers an outlook of India's current international trade position.

Table 4 International Trade Position for India, 2006

\begin{tabular}{|l|c|l|c|}
\hline Exports, total & $\$ 119.00$ & Imports, total & $\$ 184.29$ \\
\hline Top 10 Destinations of Exports & Top 10 Originations of Imports \\
\hline US & $\$ 20.90$ & China & $\$ 16.05$ \\
\hline UAE & $\$ 10.22$ & US & $\$ 11.10$ \\
\hline China & $\$ 9.52$ & Switzerland & $\$ 6.61$ \\
\hline UK & $\$ 5.33$ & Belgium & $\$ 6.38$ \\
\hline Hong Kong & $\$ 4.31$ & Germany & $\$ 8.46$ \\
\hline Singapre & $\$ 4.44$ & Australia & $\$ 7.13$ \\
\hline Germany & $\$ 4.25$ & UK & $\$ 5.49$ \\
\hline Belgium & $\$ 3.44$ & Singapre & $\$ 8.44$ \\
\hline Japan & $\$ 3.66$ & UAE & $\$ 5.53$ \\
\hline Italy & $\$ 3.41$ & Korea & $\$ 4.85$ \\
\hline
\end{tabular}

\section{WINNING STRATEGIES IN SME FINANCE}

Credit assistance to SMEs in India is included along with other national priorities. Such funding assistances to priority sector consist of the credit facilities accorded to (i) agriculture, (ii) small scale industry including loans for setting up of industrial estates, (iii) small road and water transport operators, (iv) small business, (v) professional and self employed persons, (vi) retail trade, (vii) state sponsored organizations for certain castes and tribes, (viii) education, (ix) housing, (x) consumption loans granted under the consumption credit scheme and (xi) liquidity 
support provided to Regional Rural Banks (RRBs). Due to changes in definition of the priority sector at different times, historical data may not be comparable for distinct quantitative analysis.

Policy guidelines from the government suggest that direct finance to small scale industries (SSI) shall include all loans given to SSI units which are engaged in manufacture, processing or preservation of goods and indirect finance shall include finance to any person providing inputs to or marketing the output of artisans, village and cottage industries, handlooms and to cooperatives of producers in this sector. The credit market structure in India has evolved over the years. A wide range of financial institutions exist in the country to provide credit to various sectors of the economy. These include (not counting the branches or affiliates) 183 commercial banks, 133 regional rural banks (RRBs), numerous financial institutions, 13,014 non-banking financial companies, and 1,853 urban cooperative banks. In addition to these sources of credit, short-term rural credit at the grass root level is emphasized through 31 state co-operative banks, 367 district central co-operative banks (DCCBs), 108,779 primary agricultural cooperatives. State cooperative and agricultural rural development banks (20) and primary cooperative and agricultural rural development banks (727) serve long-term credit needs in rural India.

\section{LABOR FORCE}

The International Labor Organization (ILO) recommends that developing countries must design their growth strategies and labor policies to pursue explicit employment objectives. "Employment growth in the formal segment must exceed the labor force growth in the economy, and labor market regulations and institutions must not generate strong incentives for the substitution of capital for labor. Finally, growth must occur in the non-formal segment so that output per worker there does not decline" [ILO 2008]. According to the ILO, about 73 percent of the world's 3.1 billion workers lives in developing countries, thereby creating a huge asymmetry in the distribution of the world's productive resources. The world's labor force is mostly concentrated in developing countries, but the capital and skills are located in advanced industrial countries. About 46 million workers are expected to join the labor force each year and most of them will be located from developing economies. The changes in the Indian labor force, as shown in Figure 1 suggest remedial policies required to halt the shrinking agricultural sector and to offer incentives to encourage the somewhat stagnant industrial sector. The fast growth in the services sector may suffer obstacles without adequate support of additional infrastructure developments.

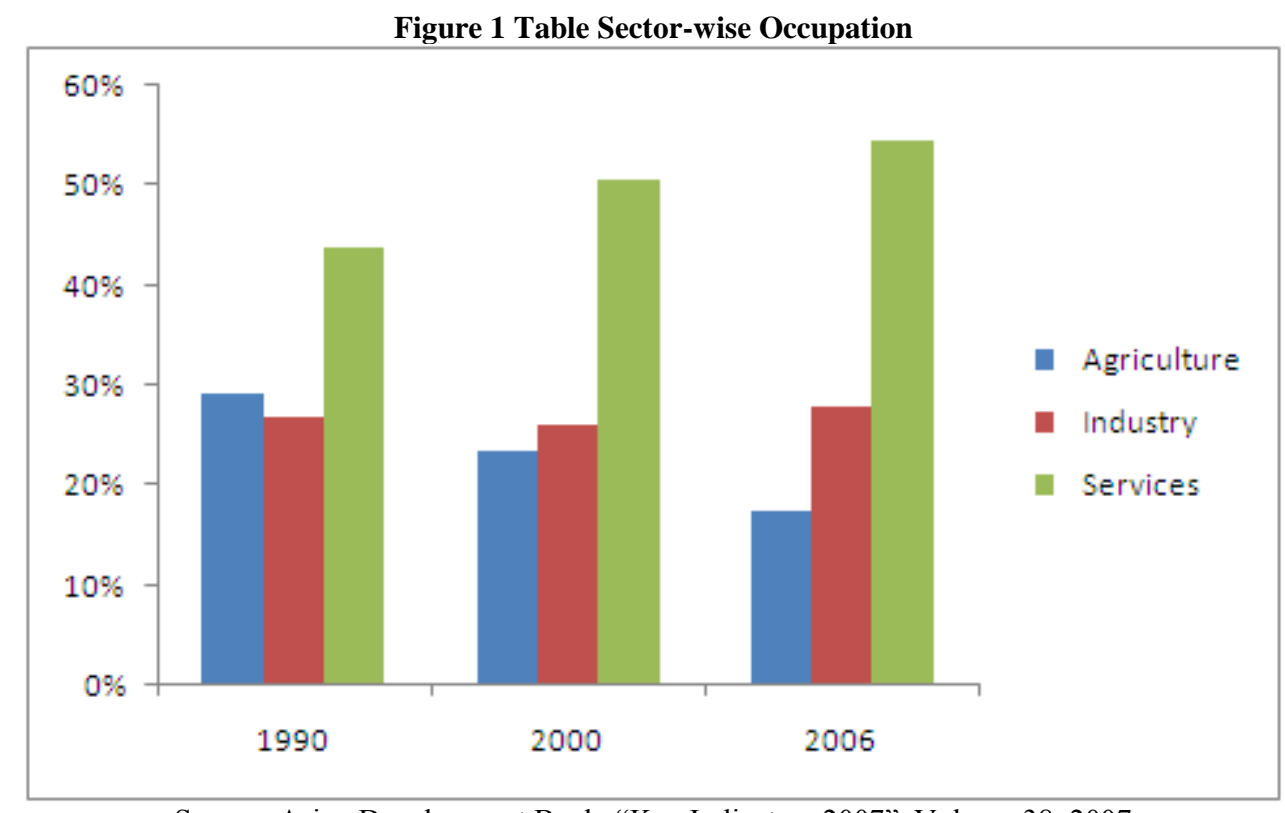

Source: Asian Development Bank, "Key Indicators 2007”, Volume 38, 2007 
Vital statistics with regard to the labor force in India are shown in Table 5.

Table 5 Labor Force Contributing to Production

\begin{tabular}{|c|c|c|}
\hline \multicolumn{3}{|l|}{ rable st } \\
\hline Year & 2000 & 2005 \\
\hline Labor Force (in millions) & 345.86 & 380.79 \\
\hline Employed & 336.61 & 368.88 \\
\hline Agriculture & 201.78 & 207.08 \\
\hline Industry & 54.89 & 69.39 \\
\hline Services & 79.94 & 92.41 \\
\hline Employed rate & $97.3 \%$ & $96.9 \%$ \\
\hline Agriculture & $59.9 \%$ & $56.1 \%$ \\
\hline Industry & $16.3 \%$ & $18.8 \%$ \\
\hline Services & $23.7 \%$ & $25.1 \%$ \\
\hline Unemployed (in millions) & 9.25 & 11.91 \\
\hline Unemployment rate & $2.67 \%$ & $3.13 \%$ \\
\hline Labor force participation rate & $37.60 \%$ & $39.20 \%$ \\
\hline Male & $53.50 \%$ & $55.10 \%$ \\
\hline Female & $20.80 \%$ & $22.40 \%$ \\
\hline
\end{tabular}

Source: Asian Development Bank, “Key Indicators 2007”, Volume 38, 2007

\section{MAJOR PROBLEMS AND CHALLENGES FOR THE SECTOR}

The major problems faced by the SSI Sector relate to availability of loan without collateral, delay in getting the loan, high cost of funds, delayed payments, marketing problems, WTO related issues, and sickness [Kamesam 2003]. About $10 \%$ of the small scale units are identified as sick and when the sickness prolongs, it leads to the closure of units and unemployment. This trend has wider implications, including funding assistance from the lending institutions turning non-performing assets. It also leads to a loss of scarce material resources and loss of existing employment [Kamesam 2002]. The recommendations offered by Lakshmanan, et al to improve the competitiveness of manufacturing goods in India will befit the SME sector completely. Continued diversification of export basket, improvement of export quality and productivity, increased technology intensity in production, enhanced R\&D activity, reduction of cumbersome regulatory environment, adding flexibility to the existing labor laws, and removal of infrastructural bottlenecks are certain to make the SMEs more innovative and participating [Lakshmanan et al 2007].

Though the credit facilities have registered a positive growth rate over the years, as shown in Table $6, \$ 20$ billion is an insufficient credit to the SMEs in an emerging market that is slated to grow at 7\% per year for the next four decades. Figure 2 illustrates the rate of growth of credit to SMEs over the same period from 1990 to 2006 . The rate of growth has neither grown at a steady pace nor shown any trace of remaining constant. 
Table 6 Amount of Credit Facilities to SMEs (1990 to 2006)

\begin{tabular}{|c|c|c|c|}
\hline Year & $\begin{array}{c}\text { Credit } \\
\text { Facilities } \\
\text { (millions) }\end{array}$ & Year & $\begin{array}{c}\text { Credit } \\
\text { Facilities } \\
\text { (millions) }\end{array}$ \\
\hline 1990 & $\$ 8,573.08$ & 1999 & $\$ 11,142.96$ \\
\hline 1991 & $\$ 6,669.64$ & 2000 & $\$ 11,297.11$ \\
\hline 1992 & $\$ 6,258.62$ & 2001 & $\$ 11,601.82$ \\
\hline 1993 & $\$ 6,369.59$ & 2002 & $\$ 11,916.46$ \\
\hline 1994 & $\$ 7,209.18$ & 2003 & $\$ 13,258.84$ \\
\hline 1995 & $\$ 7, \$ 56.17$ & 2004 & $\$ 15,219.55$ \\
\hline 1996 & $\$ 8, \$ 68.98$ & 2005 & $\$ 16,593.55$ \\
\hline 1997 & $\$ 9,146.06$ & 2006 & $\$ 20,457.72$ \\
\hline 1998 & $\$ 10,232.36$ & & \\
\hline
\end{tabular}

Source: Handbook of Statistics on the Indian Economy, 2005-06

Reserve Bank of India

Figure 2 Credit Facilities to SMEs - Annual Growth Rate

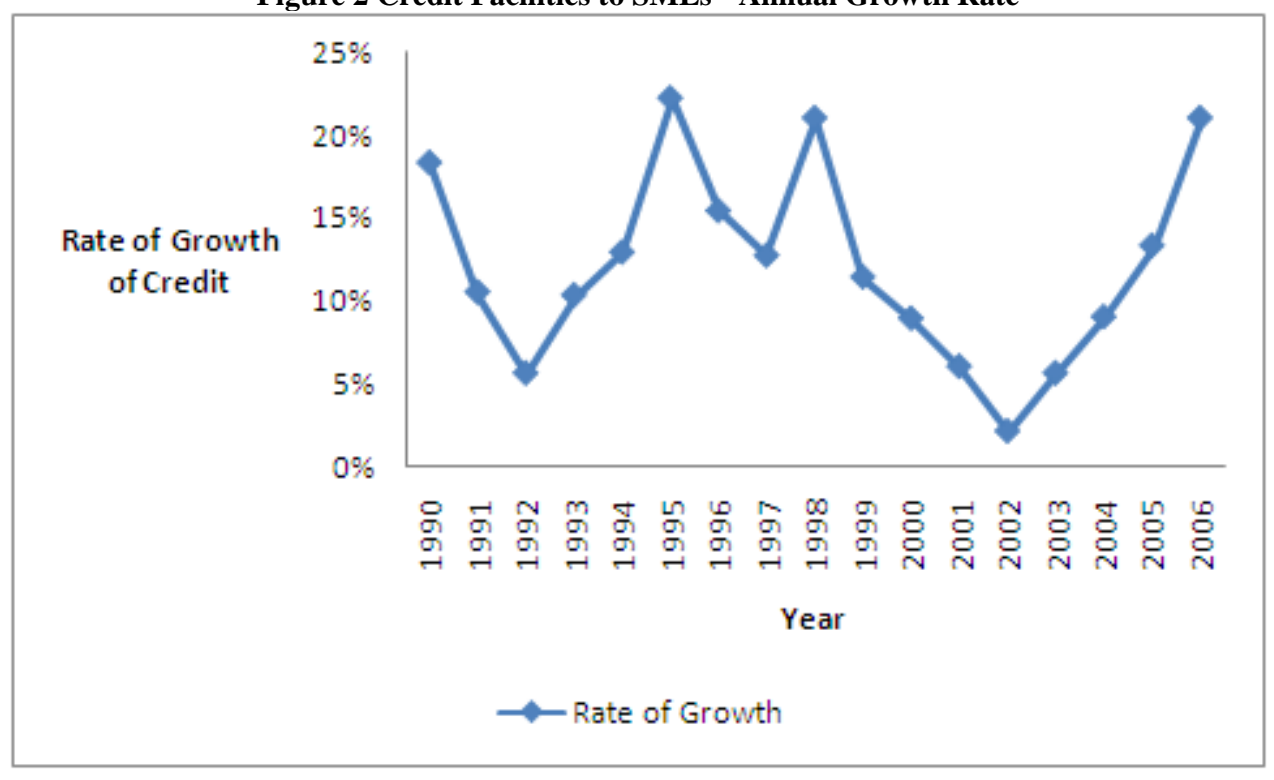

The value of production in the small scale sector has increased at $11.1 \%, 1.8 \%$, and $8.4 \%$ in the past three decades respectively. The liberalization stage has shown the implementation of market based economy, particularly in the country's exchange rates; hence the low growth in the 1990s. Table 7 presents the salient aspects of the contribution of the SMEs since 1990. 


\begin{tabular}{|l|c|c|c|}
\hline \multicolumn{4}{|c|}{ Table 7 Contribution of the SMEs for Select Years } \\
\hline & 1990 & $\mathbf{2 0 0 0}$ & $\mathbf{2 0 0 5}$ \\
\hline Number of Units (000) & 6,790 & 10,110 & 12,340 \\
\hline $\begin{array}{l}\text { Employees (000) } \\
\text { Value of Production (in }\end{array}$ & 15,830 & 23,870 & 29,490 \\
\hline $\begin{array}{l}\text { billions) } \\
\text { Exports (in billions) }\end{array}$ & $\$ 5.37 .73$ & $\$ 39.44$ & $\$ 61.31$ \\
\hline $\begin{array}{l}\text { Share of SMEs' Exports } \\
\text { to Total Exports }\end{array}$ & $29.70 \%$ & $\$ 14.93$ & $\$ 21.72$ \\
\hline
\end{tabular}

The labor force in this sector has increased by an average annual growth rate of $6 \%, 7 \%$, and $4.3 \%$ in the past three decades, while the export contribution has been around $20 \%$ during the entire time period. Thus, India has a huge potential for the SMEs and better benefits may be reaped with the advent of growing private equity market. There will be fresh venture capital inflows from outside, particularly from the industrialized economies where the growth has been low and soft.

\section{CONCLUSION}

Established companies and entrepreneurs in Asia are able to reach price-performance levels and, as a result, capture significant market share from companies in Europe and the United States through disruptive product and process innovations. Distinctively innovative management processes developed in countries, such as China and India, may also pose a threat to Western companies [Brown 2005]. India's approach to economic development remains cautious in inward foreign direct investment. The Indian government has taken a "less interventionist position regarding government regulation and direction of industry compared to that of China". Thus, entrepreneurship in general and sophisticated businesses, such as software, biotechnology, and advertising, in particular, has registered significant progress [Khanna 2004].

The country should focus on the creation of congenial environment for success and ensure that entrepreneurs have access to skills, capital and opportunities for networking and exchange to assist its new class of entrepreneurs [Gupta, 2001]. Despite its reform experience being very young, "India has made its mark in the global entrepreneurial scene. Indian citizens (for example, Sunil Mittal and Naresh Goyal) made their name known as world class entrepreneurs" [Koveos 2007]. New opportunities that arise within the country every day create the need for jobs and also an insatiable appetite for new entrepreneurial talent. The priority must be to unite the diverse units of the SMEs under an organized structure and integrate their operations into that of major global firms. The availability of three national-level Entrepreneurship Development Institutes engaged in skill development is a good step to keep the innovative spirit alive and modern. The institutional response may appear overwhelming and superfluous, but this is the best that the government can and must do until the capital and money markets grow sufficiently to address funding needs of the SMEs.

\section{REFERENCES}

1. $\quad$ Asian Development Bank, "Key Indicators 2007”, Volume 38, 2007

2. Bala Subrahmanya, M.H., "Development Strategies for Indian SMEs: Promoting Linkages with Global Transnational Corporations", Management Research News, September 2007, Vol. 30, Issue 10, pp. 762-774

3. Bresnahan, Timothy; Gambardella, Alfonson; Saxenian, AnnaLee, "Old Economy Inputs for New Economy Outcomes: Cluster Formation in the New Silicon Valleys", Industrial \& Corporate Change, December 2001, Vol. 10, Issue 4, pp. 835-860

4. Brown, John Seely, "Innovation Blowback: Disruptive Management Practices from Asia", McKinsey Quarterly, 2005 Issue 1, pp. 34-45 
5. Daokui Li, David; Junxin Feng; and Hongping Jiang, "Institutional Entrepreneurs", American Economic Review, May 2006, Vol. 96 Issue 2, pp. 358-362

6. Das, Debarshi, "Persistence of Small Scale Family Farms in India: A Note”, Journal of International Trade \& Economic Development, September 2007, Vol. 16 Issue 3, pp. 401-410

7. Ghose, Ajit, K., Majid, Nomaan, and Ernst, Christoph, "The Global Employment Challenge”, Executive Summary, International Labor Organization, 2008, pp. 1-4

8. Gupta, R., “Creating Indian Entrepreneurs. India Today”, McKinsey \& Company, February 12, 2001

9. Jauhari, Vinnie, "India's Preparedness for Knowledge Based Economy: Opportunities and Challenges", Journal of Services Research, April 2007, Vol. 7 Issue 1, pp. 59-80,

10. Khanna, Tarun, "India's Entrepreneurial Advantage”, McKinsey Quarterly, 2004 Special Edition, pp. 111114

11. Khanna, Tarun, "Billions of Entrepreneurs: How China and India Are Reshaping Their Futures and Yours", Harvard Business School Press, 2008

12. Kamesam, Vepa, Speech at the OECD "Workshop on Entrepreneurship in a Global Economy : Strategic Issues and Policies" at Budapest in the panel "Identifying the Real Policy Issues" in the Session on "Improving Financing for Entrepreneurship and SMEs" on September 9, 2003

13. Kamesam, Vepa, Speech at a Symposium on "Winning Strategies in SME Finance" organized by International Finance Corporation and FICCI at Mumbai on February 11, 2002.

14. Koveos, Peter E., "China and India: A Tale of Two Entrepreneurial Giants", Journal of Developmental Entrepreneurship, December 2007

15. Lakshmanan, L., Chinngaihlian, S., and Rajesh, Raj, "Competitiveness of India's Manufacturing Sector: An Assessment of Related Issues”, Reserve Bank of India Occasional Papers, Vol. 28, No. 1, Summer 2007, pp. 33-77

16. Narayana, M. R., "Economic Size and Performance of Dispersed and Clustered Small Scale Enterprises in India: Recent Evidence and Implications, International Journal of Social Economics, 2007, Vol. 34 Issue 9/10, pp. 599-611

17. OECD, Financial Market Trends, "Risk Capital in OECD Countries: Past Experience, Current Situation and Policies for Promoting Entrepreneurial Finance", April 2006, Issue 90, pp. 111-151

18. Singh, Gajendra; Singh, Shailender. "Distribution Strategies in the success of Entrepreneurship in Small and Medium Enterprises in India", Proceedings of the Northeast Business \& Economics Association, 2007, pp. 259-262

19. Srivastav, Nirankar; Syngkon, Ricky A. and J. Icfai, "Marketing Management and Entrepreneurship Development in a Tribal Dominated Economy: A Case Study of Small Scale Industries in East Khasi Hills District of Meghalaya:, Journal of Entrepreneurship Development, December 2007, Vol. 4 Issue 4, p28-47

20. Thukral, Inderpreet S.; Von Ehr, James; Walsh, Steven; Groen, Aard J.; Van Der Sijde, Peter; and Akmaliah Adham Khairul, "Entrepreneurship, Emerging Technologies, Emerging Markets", International Small Business Journal, February 2008, Vol. 26 Issue 1, pp. 101-116

21. Venkataramanaiah, S.; Parashar, S. P., "Enhancing the Competitiveness of SMEs through Industrial Clusters: The Indian Experience", International Journal of Technology Management \& Sustainable Development, 2007, Vol. 6 Issue 3, pp. 227-243 
International Business \& Economics Research Journal - March 2009

Volume 8, Number 3

NOTES 